\title{
DIMENZIONÁLIS MÉRÉSEK IPARI CT BERENDEZÉSSEL
}

\section{DIMENSIONAL MEASUREMENTS BY INDUSTRIAL CT}

\author{
Drégelyi-Kiss Ágota \\ Óbudai Egyetem, Bánki Donát Gépész és Biztonságtechnikai Mérnöki Kar, Anyag- \\ és Gyártástudományi Intézet, 1081 Budapest, Népszinház utca 8.; Telefon / \\ Fax:+36-1-666-5480, dregelyi.agota@bgk.uni-obuda.hu
}

\begin{abstract}
More recently, the industrial CT equipment is used not only for non-destructive analysis but to perform geometrical evaluations. The three dimensional, optical dimensional measurements made by CT are popular because the measurement time is much more less than in case of traditional 3D measurement machines, furthermore the inner geometries can be determined by non-destructive manner. In this article the design and measurement plan of an aluminum test cube by industrial CT are described and the evaluation of the measurement data are evaluated.
\end{abstract}

Keywords: dimensional measurement, industrial CT, measurement uncertainty

\section{Összefoglalás}

Az ipari gyakorlatban egyre elterjedtebben használják az ún. ipari CT berendezéseket roncsolásmentes anyagvizsgálatok mellett dimenzionális mérésekre. A CT-vel történő három dimenziós, optikai elven történő hosszúságmérések népszerủek, mivel a mérések ideje a 3D mérőgépekkel történő méretmeghatározáshoz képest lényegesen kisebb, valamint belső méretek is meghatározhatók roncsolásmentesen, amelyekre egyéb hosszmérőeszközök elérhetőség hiányában nem adtak megoldást. Cikkemben egy alumíniumból készült tesztdarab dimenzionális mérésének tervezését, folyamatát mutatom be ipari CT-vel történő meghatározás során.

Kulcsszavak: hosszmérések, roncsolásmentes vizsgálat, ipari CT, mérési bizonytalanság

\section{Bevezetés}

Az ipari CT berendezésekkel különféle forgácsolt alkatrészek geometriai mérése lehetővé vált az elmúlt évek fejlesztéseinek következtében [1,2]. A forgácsolt alkatrészek méreteinek türése a 0,01-0,003 mm tartományba esik, és ilyen méretekhez kell biztosítani, hogy a roncsolásmentes és gyorsan végrehajtható CT berendezésekkel tudjuk a méreteket meghatározni.

A méretek meghatározásának egyik feltétele, hogy a méröeszköz mérési skálája visszavezetett legyen a nemzetközi etalonra, esetünkben a méter definícióra. A CT berendezések esetén ez még nem teljes körüen megoldott, több kutató dolgozik ezen probléma megoldásán [3].

A CT-vel történő mérések során körbeforgatva a vizsgálati tárgyat a berendezésben 500-1500 2D röntgenfelvételt készítenek, amelyekből a rekonstrukció során 3D modellt alkotunk. Meg kell határozni a határfelületet matematikai módon, hogy a későbbi hosszméretek egyértelmüen meghatározhatóak legyenek. A threshold érték célszerü megválasztásával tudjuk a felületet meghatározni.

Munkám során egy alumíniumból készült kutatáshoz használt tesztdarab mérését 
végeztem el ipari CT berendezéssel, és vizsgáltam a rekonstrukciós fázisban a beállítható paraméterek hatását a geometriai mérések alakulására.

\section{Anyagok és módszerek}

\subsection{Vizsgálati darab és méretek}

Az ipari CT berendezés metrológiai tulajdonságainak vizsgálatára terveztünk egy teszt munkadarabot, amely anyaga alumínium, befoglaló mérete $90 \mathrm{~mm}$ x $90 \mathrm{~mm}$ x $90 \mathrm{~mm}$ (1. ábra).

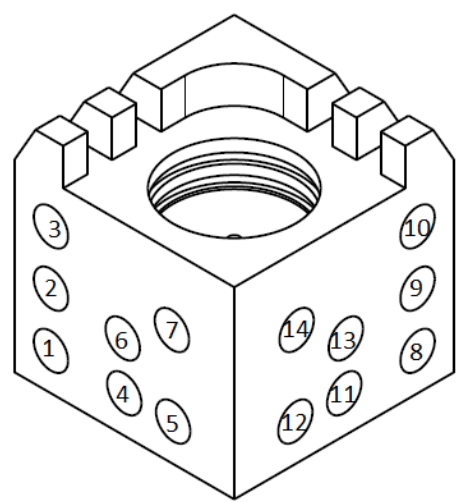

1. ábra. Alumínium vizsgálati tesztdarab a furatok sorszámaival

Jelen kutatás során a tesztdarab geometriai formái közül az oldalfelületen levő 14 $\mathrm{db} 14 \mathrm{~mm}$ névleges átmérővel rendelkező furat sugarát határoztam meg úgy, hogy a furatokba Gauss módszerrel illesztettem hengert.

\subsection{Mérés körülményei}

A dimenzionális mérésekhez $G E$ phoenix $v \mid$ tome $\mid x \mathrm{~m}$ mikro-CT berendezést használtam. 2024×2024 pixeles detektorral, $\max .320 \mathrm{~W}, 320$ kV-os röntgencső. A mérés során használt beállítások: $250 \mathrm{kV}, 360$ $\mu \mathrm{A}, 330$ ms-os képfelvétel, binning $1 \times 1$, szürők: 0,5 mm Sn és 0,5 $\mathrm{mm} \mathrm{Cu}$, felvett képek száma 1440. Az így elért voxelméret $73,44 \mu \mathrm{m}$.
A dimenzionális mérések alapja, hogy a mérések visszavezethetők legyenek, vagyis etalonhoz képest kell a méreteket meghatározni, beskálázni a kapott felvételeket. Az ipari CT berendezések esetén a kalibrálás még nem kidolgozott, közelítésekkel lehet csak élni. A jelenleg javasolt módszer, hogy lehetőség szerint a CT felvétel az adott teströl egy etalonnal együtt történjen. A CT felvétel készítése során a tesztdarab közepén rögzítettük etalonként egy két rubingömböt tartalmazó ball bart, amely esetén a két rubin-gömb közötti távolság kalibrált értéke 15,9329 mm.

A rekonstrukcióhoz használt szoftver a VGStudio Max 2.2.2. A rekonstrukció és az illesztések során több paramétert lehet változtatni. Vizsgálataim során az egy adott beállítással elkészített CT felvétel rekonstrukcióját az alábbi faktorok változtatásaival hajtottam végre:

- szoftveres korrekció a háttér sugárzás figyelembevételére a forgatás során (az ún. $R O I$ beállítás figyelembevétele vagy kikapcsolása);

- rubingömbök távolságának meghatározása automata vagy manuális threshold használatával (Rubin auto thr. vagy man. thr.);

- alumínium részeken levő méretek meghatározásához automatikus vagy manuális threshold használata (Al auto thr. vagy man. thr.);

- egy adott rekonstruált beállításokkal ismételt méret-meghatározásokat végeztem az illesztés bizonytalanságának meghatározására.

\section{Eredmények és értékelésük}

\subsection{Etalon mérése}

A CT-vel történő felvételek elkészítése után első lépésként a két rubingömb távolságát mértem meg. A mérés eredményei az 1. táblázatban találhatóak. 


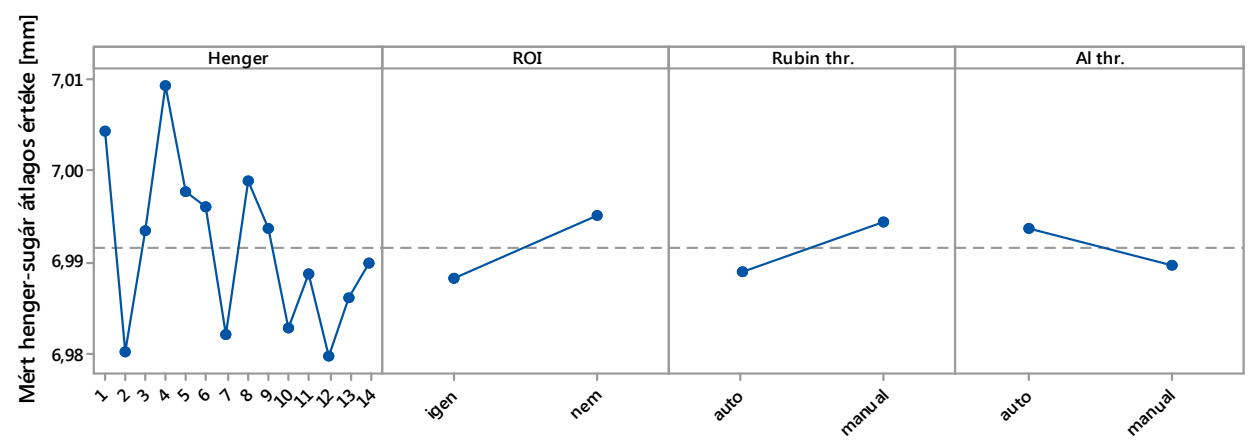

2. ábra. A mérési eredményekre vonatkozó föhatás-ábrák

1. táblázat. Rubingömbök távolságának megha-

\begin{tabular}{|c|c|c|c|c|}
\cline { 2 - 5 } \multicolumn{1}{c|}{} & \multicolumn{2}{c|}{ tározása } \\
\cline { 2 - 5 } \multicolumn{1}{c|}{} & $\begin{array}{c}\text { ROuto } \\
\text { thr. }\end{array}$ & $\begin{array}{c}\text { man. } \\
\text { thr. }\end{array}$ & $\begin{array}{c}\text { auto } \\
\text { thr. }\end{array}$ & $\begin{array}{c}\text { man. } \\
\text { thr. }\end{array}$ \\
\hline $\begin{array}{c}\text { Mért } \\
\text { érték } \\
{[\mathrm{mm}]}\end{array}$ & 15,922 & 15,908 & 15,910 & 15,907 \\
\hline $\begin{array}{c}\text { Helyes } \\
\text { érték }\end{array}$ & \multicolumn{3}{c|}{$15,9329 \mathrm{~mm}$} \\
\hline
\end{tabular}

Eredményként elmondható, hogy a beállítások jelentősen befolyásolják az etalonra vonatkozó mérés eredményét. A ball bar referencia értékét nem kaptuk vissza, a legközelebbi érték 0,01 mm-re van, de $26 \mu \mathrm{m}$ es torzítás is látható. A vizsgálatok megkezdése előtt a CT berendezés bemérése és korrekciója megtörtént egy etalonnal, elviekben vissza kellett volna kapni az etalon értékét.

Szeretném hangsúlyozni, hogy egyetlen CT felvétel készült, és csupán az adatok feldolgozási módja adja a különböző mért értékeket a rubingömbök távolságának a meghatározására. Ha nem használjuk a ROI beállítás lehetőségét, vagyis azt, hogy korrigáljuk a mérési adatokat a háttérsugárzásra a forgatás során, akkor nem nagy különbséget tapasztalunk a kétfajta threshold módszert alkalmazott mérés között, az eltérés 3 $\mu \mathrm{m}$. A ROI figyelembevételekor a threshold módszerek különbözősége jelentősen befolyásolja a méret értékét.

\subsection{Alumínium tesztdarab mérése}

A mérési eredmények adott faktor szerinti átlagos értékei az 1. ábrán látható sorszámozott furatok sugár értékeire a 2. ábrán jelennek meg. Megállapítható az ábráról, hogy átlagosan kisebb sugár értékeket kapunk mindhárom esetben, (i) ha a ROI beállítást használjuk a kiértékelés során, (ii) ha az automata threshold módszert használjuk a rubingömbök távolságának a meghatározására, valamint abban az esetben, (iii) ha az alumíniumra vonatkozó threshold beállítás kézi módszerrel történik.

Hasonló következtetéseket tudunk levonni a kölcsönhatás ábrák vizsgálatával (3. ábra). Látható, hogy az előbb említett következtetések nem csupán az összes mérés átlagára igazak, hanem közel az összes számozott furat esetén az egyik beállítás kisebb méretet ad, mint a másik beállítás (ld. első oszlop diagramjai). A ROI beállítás használata illetve negligálása esetén átlagosan 5,5 $\mu \mathrm{m}$ eltérés, a rubin threshold két szintje alkalmazása esetén átlagosan 4,6 $\mu \mathrm{m}$ eltérés adódik, valamint az alumínium tömb threshold beállításának változatásával átlagosan 3,2 $\mu \mathrm{m}$ eltérés jelentkezik.

Ezek az eltérések ANOVA módszerrel értékelve szignifikánsan jelentkeznek. Öszszehasonlításképpen az egyik kiértékelési beállítás (ROI-igen, Rubin thr.-manual, $\mathrm{Al}$ thr.-manual) ismételt vizsgálatát elvégeztem a 14 furat sugarának meghatározására. 


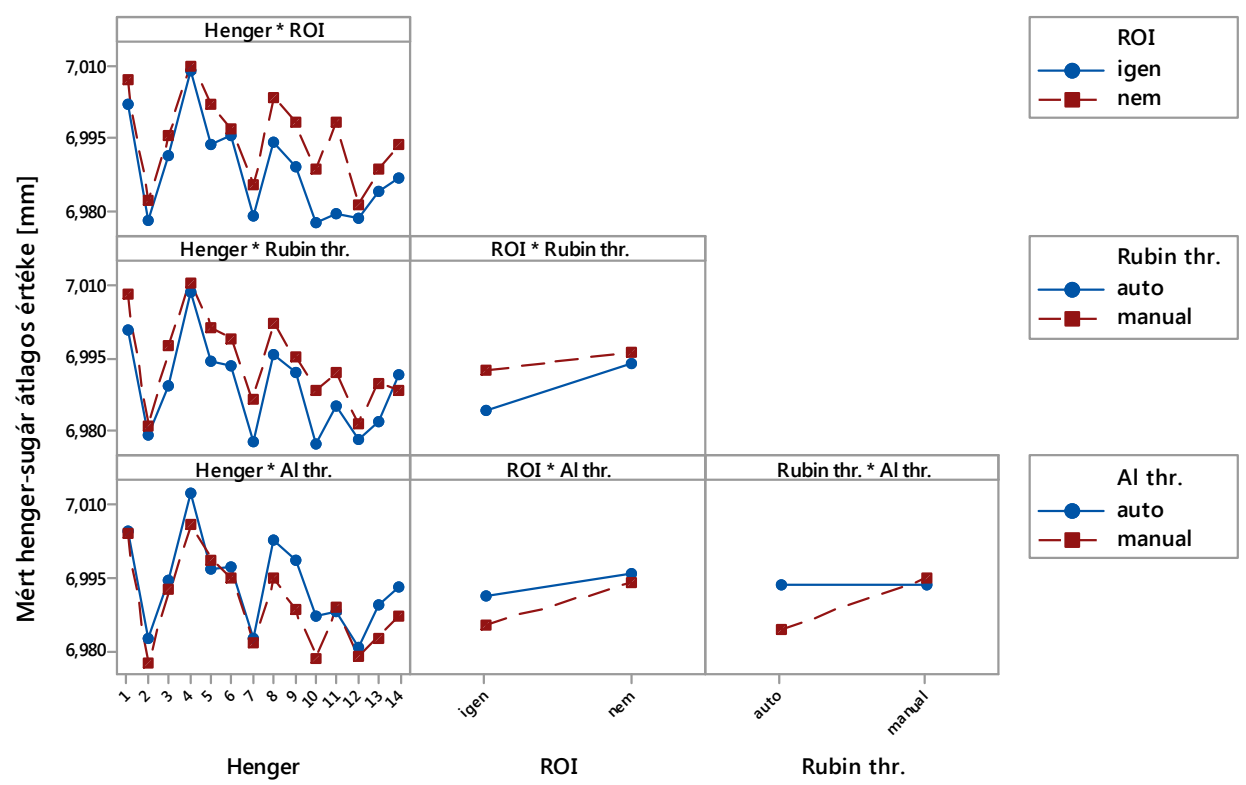

3. ábra. A mérési eredményekre vonatkozó kölcsönhatás-ábrák

Eredményként azt kaptam, hogy az egyesített ismételt vizsgálat szórása $3,7 \mu \mathrm{m}$.

\section{Következtetések}

Az ipari CT-vel történő hosszmérések bizonytalanságának meghatározása során számos tényezőt figyelembe kell venni. A faktorok, amelyek a mérés folyamatát befolyásolják nem csak a berendezés paramétereinek a beállításából adódnak, a röntgenfelvételek rekonstrukciója és az azt követő kiértékelés is jelentős hosszméretbeli eltéréseket eredményez. Munkám során rávilágítottam arra, hogy egy elkészített vizsgálati darab geometriai méreteit mennyire befolyásolják a rekonstrukció beállítási paraméterei és számítási metódusok.

Jelen munkában nem vizsgáltam a mérési hiba, vagyis a sugár mért értékek és a hengerek helyes sugár értékének az eltérését. Ehhez a furatok méreteinek a meghatározását tervezem tapintós 3D méréstechnikai módszerrel, amely lényegesen kisebb bizonytalansággal rendelkezik, mint a vizsgálandó ipari CT-vel történő mérések.

\section{Köszönetnyilvánítás}

Köszönetemet fejezem ki a Continental Hungary Kft. részére, amely biztosította számomra a kutatáshoz szükséges ipari CT berendezést, valamint Szabó Lénárdnak a mérések elvégzésében nyújtott segítségét.

\section{Szakirodalmi hivatkozások}

[1] Cantatore, A., Müller, P.: Introduction to computed tomography, DTU Mechanical Engineering, Kgs.Lyngby, Denmark, 2011

[2] Kruth J-P. et al.: Computed Tomography for Dimensional Metrology, CIRP Annals 60(2), 2011, pp. 821-842.

[3] Claverley, J. D., Leach, R.K.: A review of the existing performance verification infrastructure for micro-CMMs, Precision Engineering 39, 2015. pp. 1-15.

[4] S. Carmignato, A. Pierobon, P. Rampazzo, M. Parisatto, E. Savio: CT for industrial metrology, Accuracy and structural resolution of $C T$ dimensional measurements, Proceedings of the Conference on Industrial Computed Tomography (ICT), 2012. pp. 161-172. 